\title{
Morphological aspects of Clinostomidae metacercariae (Trematoda: Digenea) in Hoplerytrinus unitaeniatus and Hoplias malabaricus (Pisces: Erythrinidae) of the Neotropical region, Brazil
}

\author{
RAIMUNDO N.M. BENIGNO ${ }^{1}$, MARCELO KNOFF ${ }^{2}$, EDILSON R. MATOS ${ }^{3}$, \\ DELIR C. GOMES ${ }^{2}$, ROBERTO M. PINTO ${ }^{2}$ and SÉRGIO C. SÃO CLEMENTE ${ }^{4}$ \\ ${ }^{1}$ Laboratório de Parasitologia Animal, Universidade Federal Rural da Amazônia, \\ Av. Tancredo Neves, 2501, Terra Firme, 66077-901 Belém, PA, Brasil \\ ${ }^{2}$ Laboratório de Helmintos Parasitos de Vertebrados, Instituto Oswaldo Cruz, FIOCRUZ, \\ Avenida Brasil, 4365, Manguinhos, 21045-900 Rio de Janeiro, RJ, Brasil \\ ${ }^{3}$ Laboratório de Pesquisa Carlos Azevedo, Universidade Federal Rural da Amazônia, \\ Av. Tancredo Neves, 2501, Terra Firme, 66077-901 Belém, PA, Brasil \\ ${ }^{4}$ Laboratório de Inspeção e Tecnologia de Alimentos, Faculdade de Veterinária, \\ Universidade Federal Fluminense, Rua Vital Brasil, 64, Vital Brazil, 24320-340 Niterói, RJ, Brasil \\ Manuscript received on January 22, 2013; accepted for publication on August 12, 2013
}

\begin{abstract}
Species of fish of Marajó Island, State of Pará, Brazil, were examined to identify the trematodes parasitizing 102 Hoplerytrinus unitaeniatus (gold wolf fish) and 104 Hoplias malabaricus (thraira). Metacercariae of two species of trematodes, 170 specimens of Clinostomatopsis sorbens and 10 Ithyoclinostomum dimorphum were found and identified. The parasitary indices of $C$. sorbens from $H$. unitaeniatus and H. malabaricus, were $43.14 \%$ and $30.77 \%$ for prevalence, 2.52 and 1.84 for mean intensity, 1.09 and 0.57 for mean abundance and 1 to 9 and 1 to 7 for range of infection, respectively, on both fish the site of infection was the mesentery. The parasitary indices of I. dimorphum from $H$. unitaeniatus were $2.94 \%$ for prevalence, 2.66 for mean intensity, 0.08 for mean abundance, 1 to 4 for range of infection, and the sites of infection were the mesentery and the muscle. Metacercariae of I. dimorphum were collected in muscles of a specimen of $\mathrm{H}$. malabaricus, with $0.96 \%$ of prevalence, intensity of infection of 2 parasites and 0.02 of abundance. New morphological data of external and internal structures are presented. This is the first record of metacercariae of C. sorbens and I. dimorphum in Amazonian fish.
\end{abstract}

Key words: Clinostomidae, Hoplerytrinus unitaeniatus, Hoplias malabaricus, Brazil.

\section{INTRODUCTION}

The genera Hoplerythrinus and Hoplias, have a wide distribution in the Neotropical region (Godoy 1975, Buckup 1999, Oyakawa 2003, Graça and Pavanelli 2007, Oyakawa and Mattox 2009). The Hoplerythrinus unitaeniatus occurs in Central and

Correspondence to: Marcelo Knoff

E-mail:knoffm@ioc.fiocruz.br
South America, and inhabits swamps and creeks with little current, as well as flooded savannas. The Hoplias malabaricus occurs in Central and South America from Costa Rica to Argentina, being found in most rivers basins. They constitute an important fishery resource, also used in aquaculture and as ornamental fish (Froese and Pauly 2012). 
In Brazil, data on the fishery of these two species indicate their economic value related to the amount of fish obtained, and taking into account the internal acceptance of the product. Both erythrinids fish are important sources of protein for the Amazonian riverside populations and can represent up to $50 \%$ the diet of the Marajó Island communities (Marinho 2005, Murrieta et al. 2008). In the fish markets of Marajó Island these fish are usually sold whole making it to view parasites and because of the constant presence of larvae of these Clinostomidae helminths, the consumer tends to reject them during evisceration and filleting. $H$. unitaeniatus and $H$. malabaricus have been previously studied considering hygienicsanitary procedures regarding ichthyoparasitological approaches, mainly on anisakids and eustrongylids nematode species (Benigno et al. 2012).

The presence of parasites in fish products indicates a harmful sanitary problem not to be underestimated. Even considering that most of the parasitic agents are not pathogenic to humans, some species can be associated to serious diseases due to the ingestion of infected fish, caused by helminth larvae, and few species of clinostomid trematodes may rarely infect people (mainly associated to Clinostomum spp.), causing pharyngitis, laryngitis, laryngo-pharyngitis or eye infections, who have consumed raw fresh-water fish, in Japan, Korea, Thailand, India, and Israel (Williams and Jones 1994, Chung et al. 1995, Tiewchaloern et al. 1999).

Beyond the zoonotic importance of this group of parasites it is related to the disagreeable aspect they present to potential consumers of infected fishes that often are discharged either in processing facilities or during inspection procedures, causing economic losses. Reports of parasitism by a Clinostomidae trematode Clinostomum sp. in tilapia species, Oreochromis spp. in Zaire have often been disreputed or simply rejected by consumers because of parasitic worms (Kabunda and Sommerville 1984).
The metacercariae of Clinostomum sp., $C$. complanatum (Rudolphi 1814) and C. marginatum Rudolphi 1819 species usually involved with zoonosis in other countries have been reported in Brazilian freshwater fish, and H. malabaricus was included among these hosts (Dias et al. 2003a, 2006, Eiras et al. 2010).

The metacercariae of Clinostomatopsis sorbens (Braun 1899) Dolfus, 1932 has been recorded in the State of Mato Grosso on the fish H. unitaeniatus and H. malabaricus (Travassos 1940).

The metacercariae of I. dimorphum have been recorded in the fish $H$. malabaricus (Travassos et al. 1964, Pavanelli et al. 1990, Fortes et al. 1996, Moreira 2000, Gallio et al. 2007, Paraguassú and Luque 2007, Rodrigues 2010), H. unitaeniatus (Moreira 2000) and Schizodon borelli (Machado et al. 1996).

In Brazil, the adult worms of $C$. sorbens, were recorded in the esophagus of Ciconiiformes birds, from Ardeidae and Ciconiidae families (Travassos 1922, 1928, Viana 1924, Travassos et al. 1969). In Argentina, they were also recorded in Ardeidae birds (Lunaschi and Drago 2009).

Adults of Ithyoclinostomum dimorphum Diesing (1850) have been recorded parasitizing Ardeidae birds in Brazil (Travassos 1928, Lent and Freitas 1937, Travassos and Freitas 1941, 1942, Travassos et al. 1969, Arruda et al. 2001, Dias et al. 2003b, Pinto et al. 2004).

This work aimed to study the digenetic trematodes clinostomids parasites of fishes collected in Lake Arari, Marajó Island, State of Pará, Brazil, analyzing morphological structures on the helminth species, and parasitological indexes related to prevalence, mean intensity, mean abundance, infection range, and sites of infection.

\section{MATERIALS AND METHODS}

From August to December 2009, were collected 102 specimens of gold wolf fish, Hoplerytrinus unitaeniatus (Spix and Agassis 1829) of weight 
107-376g and with a standard length of 15.4-25 $\mathrm{cm}, 104$ specimens of thraira, Hoplias malabaricus (Bloch 1794), of weight 110-530g and with a standard length of $17.8-27.2 \mathrm{~cm}$, in the Arari Lake, Marajó Island, State of Pará (PA), Brazil (00³9'48" S, 49¹0'30" W). The fish were kept in isothermic boxes with ice and transported to the Laboratório de Parasitologia Animal da Universidade Federal Rural da Amazônia, Campus Belém, PA. After tegumental surface was inspected, the specimens were necropsied, the organs were separated, and transfered to the Petri dishes with $0.65 \% \mathrm{NaCl}$ solution and analyzed under stereoscopic microscope. The fish fillets were obtained by incision of musculature, from area close to the operculum to caudal fin, analyzed by candling table, and the parasites were collected. For morphologic and morphometric studies, whole mounts of the metacercariae were made according to Amato et al. (1991) and Eiras et al. (2006) methodology. Drawings were made with the aid of a drawing tube connected to a Olympus BX 41 brightfield microscope. For studies in scanning electron microscope (SEM), metacercariae samples were fixed in $2.5 \%$ glutaraldeid in a sodium cacodilate buffer solution $0.1 \mathrm{M}, \mathrm{pH} 7.4$, submitted to six washings with the same buffer at intervals of 15 minutes and post-fixed in $1 \%$ osmium tetroxide, dehydrated in a graded ethanol series $\left(20-100^{\circ} \mathrm{GL}\right)$ for one hour each step, $\mathrm{CO}_{2}$ critical-point dried, coated in gold (20-25 nm deposited) and examined, and images were obtained by digital aquisition system using a scanning electronic microscope LEO $1450 \mathrm{VP}$, under an accelerating voltage of 15 Kvolts in the Laboratório de Microscopia Eletrônica do Instituto Evandro Chagas (IEC), Belém, PA. The digenetic trematodes metacercariae were identified based on Kanev et al. (2002). On the description the terms forebody and hindbody followed sensu Manter (1970). Measurements were in milimetres $(\mathrm{mm})$, with the range followed by means indicated in parentheses. Prevalence, intensity, mean intensity, abundance, and mean abundance were obtained in accordance with Bush et al. (1997), the range of infection and infection sites of each helminth species, were also presented. Voucher specimens were deposited in the Coleção Helmintológica do Instituto Oswaldo Cruz (CHIOC), State of Rio de Janeiro, Brazil. The studied metacercariae were compared with adult and metacercaria specimens of different states of Brazil deposited on CHIOC.

\section{RESULTS}

In both fish species analyzed, living and nonencysted clinostomid metacercariae specimens of two different species described below, were found.

Clinostomoidea Lühe, 1901

Clinostomidae Lühe, 1901

Clinostominae Lühe, 1901

Clinostomatopsis Dollfus, 1932

Clinostomatopsis sorbens (Braun, 1899) Dollfus, 1932 (Figures 1a-b, 2a-b)

\section{GENERAL DESCRIPTION}

Body stout, linguiform, convex dorsally and concave ventrally (Figure 1a). Body surface, smooth without demarcated ridges or rings, and tegument aspinous. Oral sucker subterminal, small, surrounded by imcomplete collar-like fold (Figure 2a, b). Ventral sucker, well developed, strongly muscular, in anterior half of body, opening subtriangular, marked by a groove around it (Figure 2a, c). Prepharynx short and pharynx well developed. Caeca simple, long, slightly sinuous. Testes tandem, large, deeply lobed, in posterior half of body; cirrus-sac, median, intertesticular, intercecal, containing seminal vesicle coiled. Genital pore, median, intertesticular, slightly protuberant (Figures 1a, b, 2a, d). Ovary, intercecal, intertesticular, below the cirrus-sac. Uterus tubular, intercecal, median, extends to above of anterior testis and opens into uterine sac, not reaching the ventral sucker level. Metraterm, ventral to cirrus- 
sac. Vitelline follicles, extending in extra-, infra-, and supracecal fields from hindbody until half of forebody below cecal bifurcation, confluent below to posterior testis; vitelloduct anterior to ovary. Mehlis' gland larger than ovary, latero-sinistral to ovary, posterior to cirrus-sac (Figure 1a, b). Excretory vesicle Y-shaped; excretory pore dorsoterminal (Figure 1a).
MEASUREMENTS

Of three specimens from Hoplerytrinus unitaeniatus: Body 7.00-9.10 (7.70) long, 1.45-1.80 (1.58) wide. Hindbody 4.15-5.48 (4.68) long; forebody 1.552.32 (1.81) long. Oral sucker 0.27-0.30 (0.29), long, 0.41-0.45 (0.43) wide; prepharynx 0.05 long, 0.15-0.25 (0.20) wide; pharynx 0.30-0.39 (0.35) long, 0.27-0.32 (0.29) wide. Caeca 4.92-6.20 (5.68)
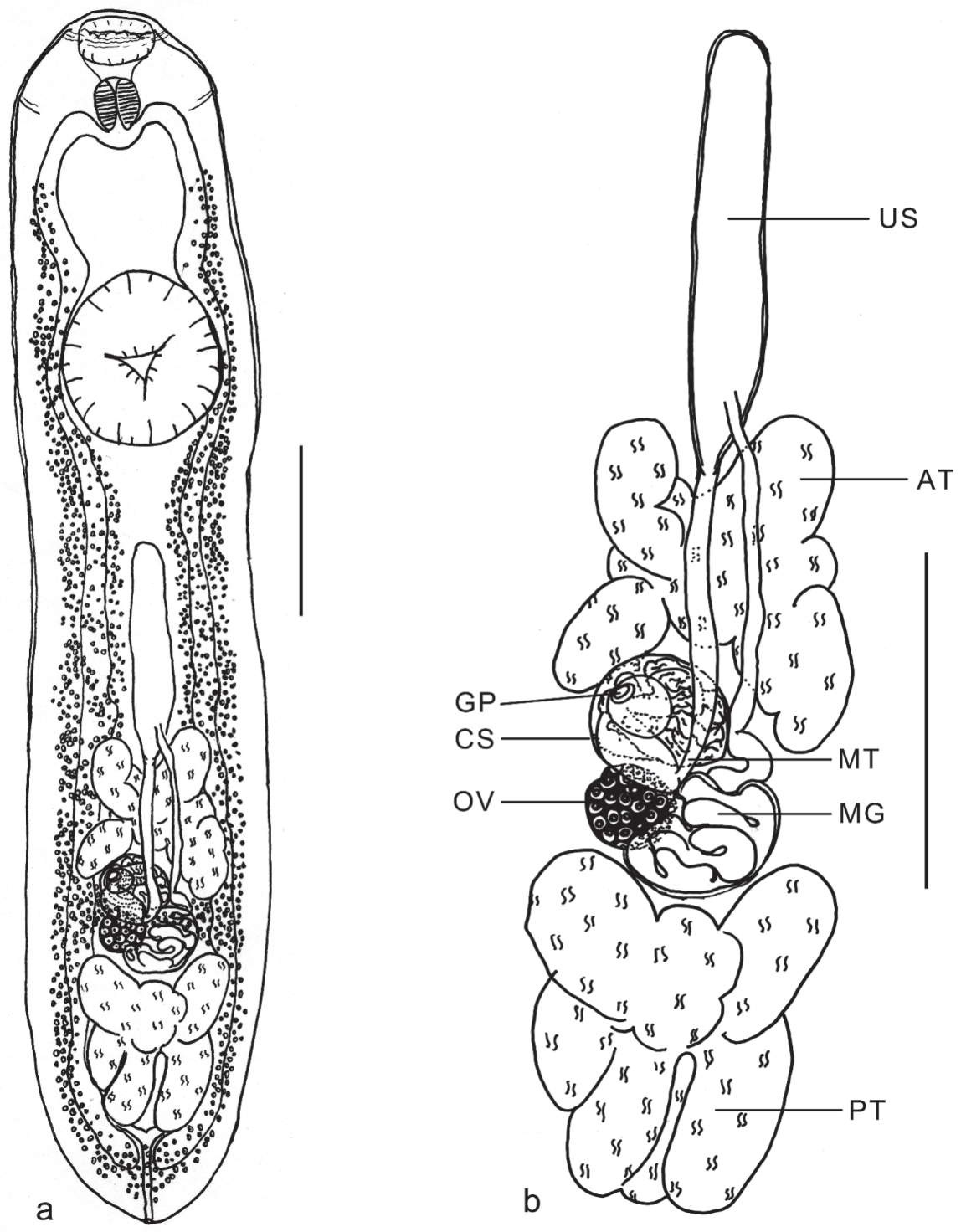

Figure 1 - Metacercaria of Clinostomatopsis sorbens from Hoplerytrinus unitaeniatus: a. Total, ventral view. b. Detail of genital organs, anterior testis (AT), posterior testis (PT), ovary (OV), Mehlis' gland (MG), uterine sac (US), metraterm (MT), cirrus-sac (CS) and genital pore (GP). The scale bars in $\mathbf{a}$ and $\mathbf{b}=1.0 \mathrm{~mm}$. 

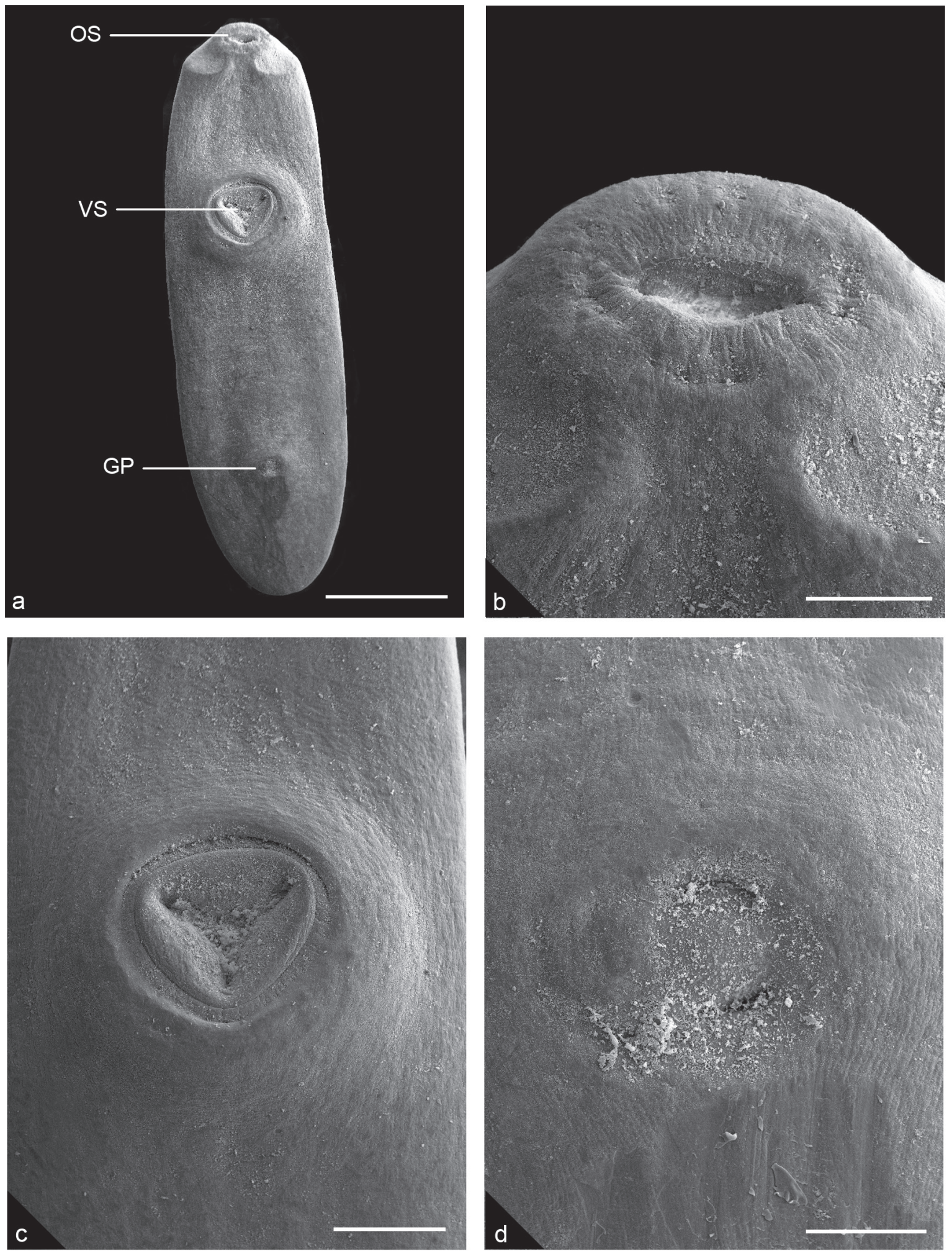

Figure 2 - Metacercaria of Clinostomatopsis sorbens from Hoplerytrinus unitaeniatus by SEM: a. Total, ventral view, oral sucker (OS), ventral sucker (VS) and genital pore (GP). b. Detail of oral sucker. c. Detail of ventral sucker. d. Detail of genital pore. The scale bars in $\mathbf{a}=1.0 \mathrm{~mm}, \mathbf{b}=0.05 \mathrm{~mm}, \mathbf{c}=0.3 \mathrm{~mm}$ and $\mathbf{d}=0.075 \mathrm{~mm}$. 
long, 0.06-0.24 (0.16) wide. Ventral sucker 1.071.30 (1.22) long, 1.00-1.17 (1.11) wide. Anterior testis 0.78-1.04 (0.89) long, 0.68-0.89 (0.81) wide; posterior testis $0.73-1.08$ (0.88) long, 0.58-0.90 (0.74) wide; cirrus-sac 0.31-0.48 (0.40) long, 0.37$0.42(0,40)$ wide. Ovary 0.14-0.22 (0.19) long, 0.15-0.23 (0.19) wide. Uterine sac 1.12-2.00 (1.62) long, 0.21-0.25 (0.23) wide.

Of three specimens from Hoplias malabaricus: Body 7.00-8.10 (7.50) long, 1.60-2.05 (1.87) wide. Forebody 1.87-2.32 (2.15) long; hindbody 3.864.66 (4.13) long. Oral sucker 0.45-0.48 (0.47) long, 0.27-0.30 (0.28) wide; prepharynx 0.07-0.12 (0.09) long, 0.20 wide; pharynx $0.40-0.45$ (0.42) long, 0.34-0.38 (0.36) wide. Caeca 6.29-7.52 (6.82) long, 0.29-0.50 (0.37) wide. Ventral sucker 1.17-1.27 (1.21) long 1.12-1.22 (1.16) wide. Anterior testis 0.55-0.91 (0.76), 0.63-0.90 (0.76) wide; posterior testis $0.65-0.87$ (0.78) long, 0.53-0.70 (0.60) wide; cirrus-sac 0.51-0.60 (0.55) long, 0.33-0.38 (0.36) wide. Ovary 0.18-0.22 (0.20) long, 0.13-0.21 (0.17) wide; uterine sac 1.30-1.60 (1.45) long, 0.22-0.30 $(0.26)$ wide.

TAXONOMIC SUMMARY

Hosts: Hoplerytrinus unitaeniatus (Spix and Agassis 1829) and Hoplias malabaricus (Bloch, 1794).

Locality: Arari Lake, Marajó Island, PA, Brazil.

Site of infecction: Mesentery.

Infected fish: $44 \mathrm{H}$. unitaeniatus and $32 \mathrm{H}$. malabaricus.

Numbers of collected specimens: 111 ( $H$. unitaeniatus) and 59 (H. malabaricus).

Prevalence: $43.14 \%$ (H. unitaeniatus) and 30.77\% (H. malabaricus).

Mean intensity: 2.52 (H. unitaeniatus) and 1.84 (H. malabaricus).

Mean abundance: 1.09 (H. unitaeniatus) and 0.57 (H. malabaricus).

Range of infection: 1-9 (H. unitaeniatus) and 1-7 (H. malabaricus)
Material deposited: From H. unitaeniatus (CHIOC 35769, 37520 a-b, wet material and CHIOC 37521, whole mount). From Hoplias malabaricus (CHIOC 35770, wet material and $37522 \mathrm{a}-\mathrm{c}$, whole mount). Material examined: 107 adults. Adults from Mycteria americana L., Parapanema, State of São Paulo, (CHIOC $163(n=3)$ and $8180(n=59)$, wet material); São João, State of Mato Grosso (CHIOC 3493-4 ( $\mathrm{n}=2$ ), whole mount and CHIOC 3531-2 ( $\mathrm{n}=39), 3734$ ( $\mathrm{n}=1)$, wet material); São Lourenço River, State of Mato Grosso (CHIOC 3909 (n=1), wet material); Jaurú, State of Mato Grosso (CHIOC $6361(\mathrm{n}=2)$, wet material). 2 metacercariae. Metacercariae from Hoplias malabaricus (Bloch, 1794), Salobra, State of Mato Grosso (CHIOC 11288 ( $\mathrm{n}=1)$, whole mount); from Hoplerytrinus unitaeniatus, Salobra, State of Mato Grosso (CHIOC 11289 (n=1), whole mount).

REMARKS

Clinostomatopsis sorbens (Braun 1899) Dollfus, 1932 was described by Diesing (1850) as Distomum dimorphum from samples collected in specimens of Mycteria americana (= Ciconia americana) (Ciconiidae) in Brazil. Later, Dollfus (1932) created the genus Clinostomatopsis for the specimens described by Diesing (1850). Species of the genus Clinostomatopsis Dollfus, 1932 are known to be parasitizing the esophagus of neotropical birds, characterized by the presence of cirrus-sac and genital pore intertesticular (Lunaschi and Drago 2009).

For generic diagnose, Kanev et al. (2002) was used, and specific diagnose was based on descriptions of Travassos et al. (1969) and Lunaschi and Drago (2009), and the present paper adds details about external and internal structures, mainly on suckers, genital pore and terminal genitalia.

In Brazil it was reported in Ardea coccoi, M. americana and Jabiru mycteria (Travassos 1922, 1928, Viana 1924, Travassos et al. 1969), and in Argentina from Tigrisoma lineatum (Lunaschi and 
Drago 2009). It was reported in H. malabaricus and H. unitaeniatus in Salobra, State of Mato Grosso, Brazil (Travassos 1940). This is the first report of metacercariae of $C$. sorbens in Amazonian fish.
Ithyoclinostominae Yamaguti, 1958

Ithyoclinostomum Witenberg, 1925

Ithyoclinostomum dimorphum (Diesing, 1850)

Witenberg, 1926 (Figs. 3a-b, 4a-d)
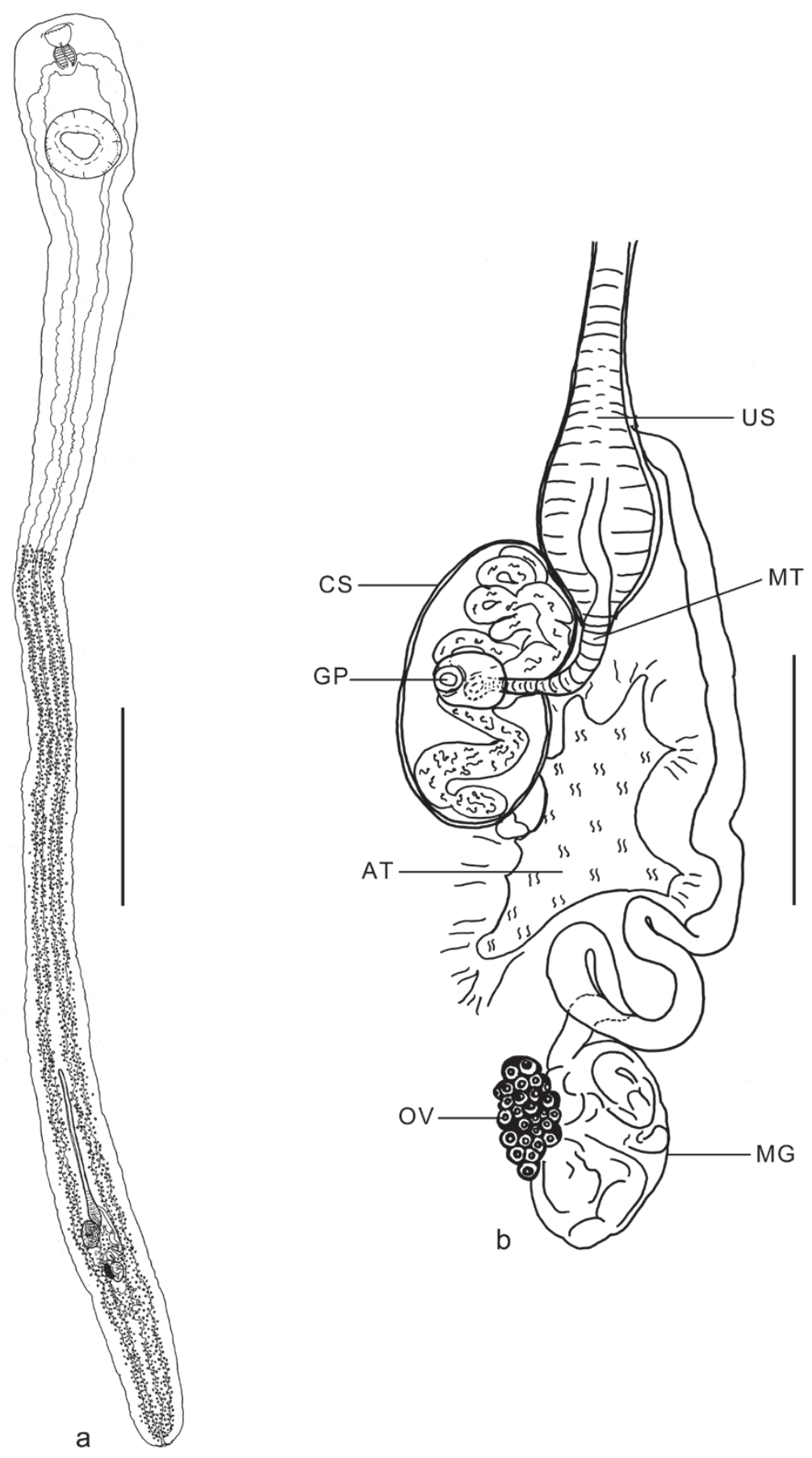

Figure 3 - Metacercaria of Ithyoclinostomum dimorphum from Hoplerytrinus unitaeniatus. a. Total, ventral view. b. Detail of genital organs, anterior testis (AT), ovary (OV), Mehlis' gland (MG), uterine sac (US), metraterm (MT), cirrus-sac (CS) and genital pore (GP). The scale bars in $\mathbf{a}=3.2 \mathrm{~mm}$ and $\mathbf{b}=0.4 \mathrm{~mm}$. 

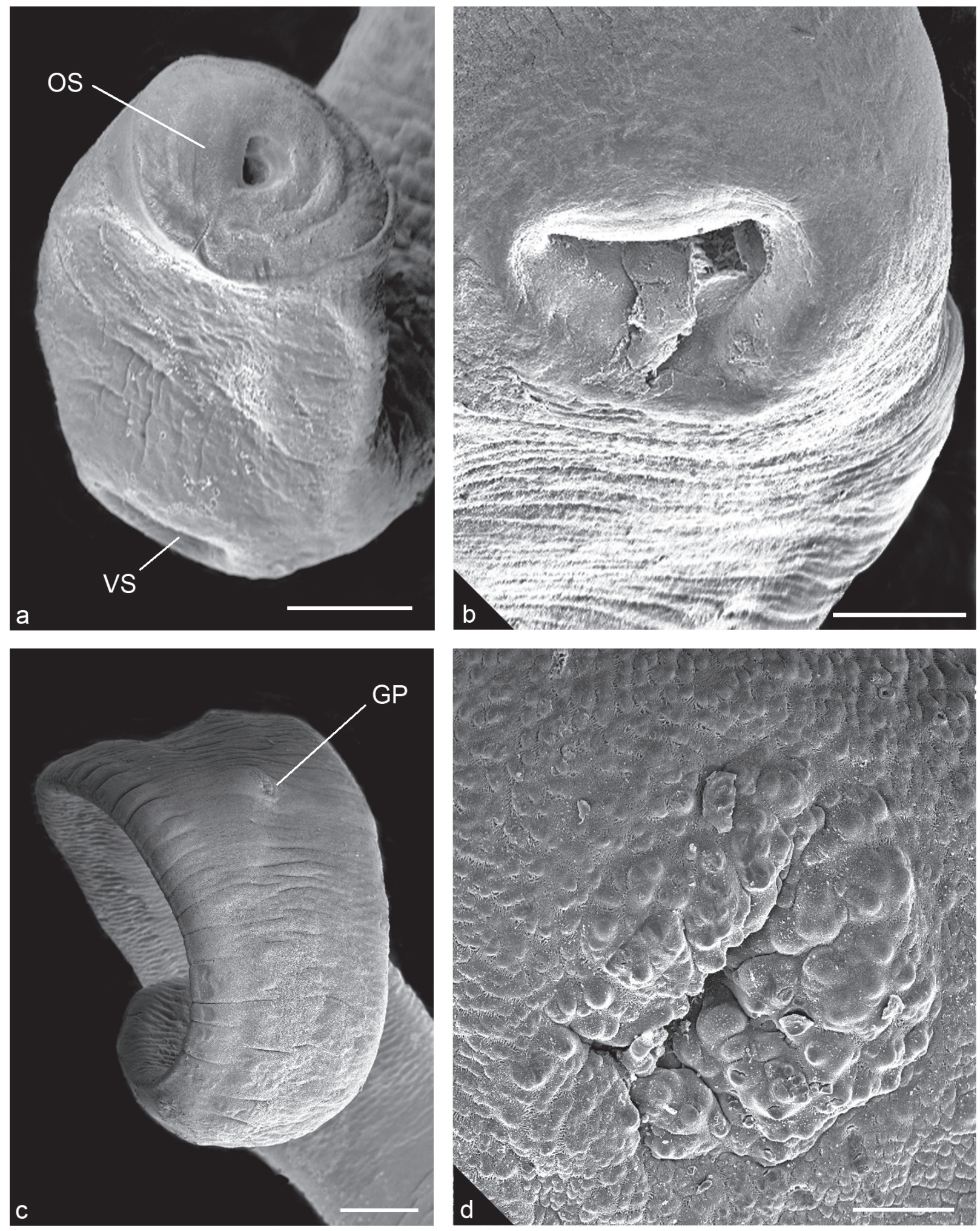

Figure 4 - Metacercaria of Ithyoclinostomum dimorphum from Hoplerytrinus unitaeniatus by SEM: a. Anterior end, ventral view, oral sucker (OS) and ventral sucker (VS). b. Detail of ventral sucker. c. Posterior end, ventral view, genital pore (GP). d. Detail of genital pore. The scale bars in $\mathbf{a}$ and $\mathbf{c}=0.5 \mathrm{~mm}, \mathbf{b}=0.3 \mathrm{~mm}$ and $\mathbf{d}=0.05 \mathrm{~mm}$. 


\section{GENERAL DESCRIPTION}

Body elongated, flattened (Figure 3a). Body surface with rounded sensory papillae, furrows and rings forming superficial annulations, dorsal and ventral, both in the forebody and hindbody (Figure 4a, b, c). Oral sucker, terminal, triangular aperture, surrounded by an expansion of the body wall such as collar-like and radial furrows in the surface (Figure 3a, 4a); pharynx present. Caeca simple, long, without lateral branches or diverticula. Ventral sucker, near anterior extremity of body, close to oral sucker, subtriangular aperture (Figures 3a, 4a, b). Testes lobed, medians, intercecals, in the posterior half of body; cirrus-sac, destro anterolateral to anterior testis, intercecal, internal seminal vesicle coiled (Figure 3a, b). Genital pore, ventral to cirrus-sac, slightly prominent, surrounded by tegumental rugosities and papillae (Figures 3b, 4c, d). Ovary, intertesticular (Figure 3a, b). Uterus, intercecal, originating from the Mehlis' gland, ascending sinistral to anterior testis reaching uterine sac (Figure 3a, b). Uterine sac elongated, median, intercecal. Metraterm, ventro-lateral to cirrus-sac, converging in a genital atrium (Figure 3b). Vitelline follicles, caecals, extending from hindbody to the end of the first third of body, below cecal bifurcation, confluent on posterior end; vitelloduct anterior to ovary; considerable space free of internal organs between ventral sucker and anterior limit of vitellarium (Figure 3a). Mehlis' gland larger than ovary, median, between testis, latero-dorsal to ovary (Figure 3a, b). Excretory vesicle Y-shaped; excretory pore dorso-terminal (Figure 3a).

\section{MEASUREMENTS}

Of one specimen from Hoplerytrinus unitaeniatus: Body 23.55 long, 1.9 maximum width. Forebody 1.55 long, hindbody 20.85 long. Oral sucker 0.36 long, 0.40 wide; pharynx 0.32 long, 0.23 wide. Caeca 22.85 long, 0.42 wide. Ventral sucker 1.15 long, 1.25 wide. Anterior testis 0.47 long, 0.34 wide; posterior testis 0.45 long, 0.23 wide; cirrussac 0.45 long, 0.27 wide. Ovary 0.18 long, 0.12 wide. Uterine sac 2.5 long, 0.25 maximum width.
TAXONOMIC SUMMARY

Hosts: Hoplerytrinus unitaeniatus and Hoplias malabaricus.

Locality: Arari Lake, Marajó Island, PA, Brazil.

Site of infecction: Mesentery and musculature of $H$. unitaeniatus and musculature of $H$. malabaricus. Infected fish: $3 \mathrm{H}$. unitaeniatus and $1 \mathrm{H}$. malabaricus. Numbers of collected specimens: 8 (H. unitaeniatus) and 2 (H. malabaricus).

Prevalence: $2.94 \%$ (H. unitaeniatus) e $0.96 \%$ (H. malabaricus).

Mean intensity: 2.67 (H. unitaeniatus).

Intensity of infection: 8 (H. unitaeniatus) and 2 (H. malabaricus).

Mean abundance: 0.08 (H. unitaeniatus).

Range of infection: 1-4 (H. unitaeniatus).

Material deposited: From H. unitaeniatus (CHIOC 35768, wet material and CHIOC 37519 whole mount).

Material examined: 30 adults. Adults from Nicticorax sp., Pirassununga, State of São Paulo (CHIOC $156(\mathrm{n}=1)$ and $8316(\mathrm{n}=2)$, wet material); from Ardea cocoi Linnaeus, 1766, Paraná River, State of Paraná (CHIOC 2405 ( $\mathrm{n}=6$ ), wet material), São João, State of Mato Grosso (CHIOC 3533 $(\mathrm{n}=1), \quad$ CHIOC $3534 \quad(\mathrm{n}=1)$, whole mount), Manguinhos, State of Rio de Janeiro (CHIOC 7972 $(\mathrm{n}=1)$, wet material), Marajó Island, PA (CHIOC 10586 ( $n=1)$, wet material), Salobra, State of Mato Grosso (CHIOC $12810(\mathrm{n}=2), 12821(\mathrm{n}=1), 12938$ $(n=1), 13357(n=1)$, wet material) and Barão de Melgaço, State of Mato Grosso (CHIOC 34662 $(\mathrm{n}=7)$, wet material); from Tigrisoma brasiliense (L., 1758), São João, State of Mato Grosso (CHIOC 3520-2 ( $\mathrm{n}=5)$, wet material). 5 metacercariae. Metacercariae from Hoplias malabaricus, Juparaná Lagoon, State of Espírito Santo (CHIOC 29427 $(\mathrm{n}=1)$, whole mount) and Lages Reservoir, State of Rio de Janeiro (CHIOC 35433 ( $\mathrm{n}=3$ ), wet material); from Schizodon borellii (Boulenger 1900), Paraná River, Porto Rico, State of Paraná (CHIOC 32984 $(\mathrm{n}=1)$, wet material). 
REMARKS

Adults of I. dimorphum have been reported parasitizing birds, A. cocoi, from State of Pará and State of Mato Grosso and Paraná River Basin (Travassos 1928, Lent and Freitas 1937, Travassos and Freitas 1941, 1942, Travassos et al. 1969, Dias et al. 2003b, Pinto et al. 2004), and from Nycticorax sp. and Tigrisoma lineatum of State of São Paulo and State of Mato Grosso do Sul (Arruda et al. 2001) and Ardea alba and Nycticorax nycticorax from Mato Grosso wetland (Pinto et al. 2004). Lent and Freitas (1937) have reported it from the same locality of the present study, which corroborates with our findings.

Metacercariae of I. dimorphum were reported from H. malabaricus of State of Espírito Santo, (Travassos et al. 1964); State of Paraná (Pavanelli et al. 1990); State of Rio Grande do Sul (Weiblen and Brandão 1992, Fortes et al. 1996, Gallio et al. 2007, Rodrigues 2010); State of Rio de Janeiro (Paraguassú and Luque 2007); from $H$. malabaricus and $H$. unitaeniatus of State of Minas Gerais (Moreira 2000), Schizodon borelli of High Paraná River Basin (Machado et al. 1996). This is the first report of metacercariae of I. dimorphum in Amazonian fish.

For generic diagnose Kanev et al. (2002) was used and specific diagnose was based on descriptions of Lent and Freitas (1937) and Travassos et al. (1969), and the present paper adds details about external and internal structures, mainly on suckers, genital pore and terminal genitalia.

In Brazil that metacercaria was reported parasitizing the mesentery, musculature, heart, esophagus, cloaca, gills, opercula and fins (Pavanelli et al. 1990, Moreira 2000, Rodrigues 2010). In the present study, the prevalence indices were lower than those recorded in H. malabaricus by Pavanelli et al. (1990), Weiblen and Brandão (1992), Paraguassú and Luque (2007) and Rodrigues (2010), but the mean intensity of infection was very close to those recorded by Pavanelli et al. (1990) (1.53), Weiblen and Brandão (1992) (2.8), and Rodrigues (2010) (2.52), this may be related to different ecological factors of the collection locations.

Dias et al. (2003b) by SEM described the oral sucker aperture of $I$. dimorphum as eliptical, which differs from the specimens studied in the present work, which showed apertures being triangular; but are in accordance with body surface with rounded sensory papillae, furrows and rings forming superficial annulations, dorsal and ventral, both in the forebody and hindbody (Figures 3a-b, 4a-d) and ventral sucker with subtriangular aperture (Figures 3a-b).

\section{DISCUSSION}

This is the first report of $C$. sorbens and $I$. dimorphum metacercariae in Amazonian fish species, adding morphological contributions on the external and internal structures mainly on suckers, genital pore, and terminal genitalia, which will be useful for future researches. The data obtained from this study on fish species caught in Arari Lake, Marajó Island confirm the role that these fish play in the life cycle of $C$. sorbens e I. dimorphum.

The presence of living and non-encysted clinostomid metacercariae species findings in this study on both fish species, brings out certain interesting facts concerning hygienic-sanitary, and about the potential hazard to human health, because other Clinostomatidae species have been reported to cause laryngitis, laryngo-pharigitis and in also an eye infection, or even have often been rejected by consumers because of their repugnance aspect when they are present on the musculature, viscera or abdominal cavity (Kabunda and Sommerville 1984, Williams and Jones 1994, Chung et al. 1995, Tiewchaloern et al. 1999). The previous species of clinostomids were involved in human infections belonging to other known species, we suggest further investigation concerning the role of these Brazilian clinostomids, because the visual analysis of the parasite species (visible and sometimes very large) of the contaminated fish specimens, take it into account that their discharge is recommended and foreseen 
by the legislation of several countries including Brazil, Spain and France, among others (Brasil 2007).

\section{ACKNOWLEDGMENTS}

The authors would like to thank Heloisa Nogueira Diniz (Serviço de Produção e Tratamento de Imagens do Instituto Oswaldo Cruz, FIOCRUZ) for processing the figures; Dr. José Antonio Picanço Diniz of Laboratório de Microscopia Eletrônica, Instituto Evandro Chagas for his assistance in the SEM; Dr. Wolmar Benjamin Wosiacki of Museu Paraense Emílio Goeldi for the fish identification; and the Conselho Nacional de Desenvolvimento Científico e Tecnológico (CNPq) for partial financial support.

\section{RESUMO}

Espécies de peixes da Ilha de Marajó, Estado do Pará, Brasil, foram examinadas para identificar os trematódeos parasitando 102 Hoplerytrinus unitaeniatus (jejú) e 104 Hoplias malabaricus (traíra). Identificados como Clinostomatopsis sorbens e Ithyoclinostomum dimorphum. Os índices parasitários de $C$. sorbens de $H$. unitaeniatus e $H$. malabaricus, foram $43,14 \%$ e $30,77 \%$ de prevalência, 2,52 e 1,84 de intensidade média, 1,09 e 0,57 de abundância média e 1 a 9 e 1 a 7 de variação da amplitude de infecção, respectivamente, em ambos o sítio de infecção foi o mesentério. Os índices parasitários de $I$. dimorphum de $H$. unitaeniatus foram $2,94 \%$ de prevalência, 2,66 de intensidade média, 0,08 de abundância média, 1 a 4 de variação da amplitude de infecção, e os sítios de infecção foram o mesentério e a musculatura. Metacercárias de I. dimorphum foram coletadas na musculatura de um espécime de H. malabaricus, com $0,96 \%$ de prevalência, com intensidade de infecção de 2 parasitos e 0,02 de abundância. São apresentadas novos dados sobre a morfologia das estruturas externas e internas. Este é o primeiro registro de metacercárias de C. sorbens e de I. dimorphum em peixes amazônicos.

Palavras-chave: Clinostomidae, Hoplerytrinus unitaeniatus, Hoplias malabaricus, Brasil.

\section{REFERENCES}

Amato JFR, BöEger WA AND Amato SB. 1991. Protocolos para laboratório: coleta e processamento de parasitos de pescado. Seropédica: Gráfica da Universidade Federal Rural do Rio de Janeiro, 81 p.

Arruda VS, PInTo RM AND Muniz-PEREIRA LC. 2001. New host and geographical records for helminthes parasites of Ardeidae (Aves, Ciconiiformes) in Brazil. Rev Bras Zool 18: 225-232.

Benigno RnM, São Clemente SC, Matos ER, Pinto RM, GOMES DC AND KNOFF M. 2012. Nematodes in Hopleritrinus unitaeniatus, Hoplias malabaricus and Pygocentrus nattereri (Pisces Characiformes) in Marajó Island, Brazil. Rev Bras Parasitol Vet 21(2): 165-170.

BRASIL. 2007. Ministério da Agricultura, Pecuária e Abastecimento. Legislação: RIISPOA/ Secretaria de Defesa Agropecuária. Departamento de Inspeção de Produtos de Origem Animal. Brasília: MAPA/SDA/ DIPOA, $252 \mathrm{p}$.

BUCKUP PA. 1999. Sistemática e biogeografia de peixes de riachos. In: Caramaschi EP, Mazzoni R and Peres-Neto PR (Eds), Ecologia de Peixes de Riachos, Série Oecologia Brasiliensis, v. 6, Rio de Janeiro: PPGE-UFRJ, p. 95-142.

Bush AO, LAFFerTy KD, LOTZ JM AND SHOSTAK AW. 1997. Parasitology meets Ecology on its own terms: Margolis et al., revisited. J Parasitol 83: 575-583.

Chung DI, Moon CH, Kong HH, ChOI DW AND Lim DK. 1995. The first human case of Clinostomum complanatum (Trematoda: Clinostomidae) infection in Korea. Korean J Parasitol 33(3): 219-223.

Dias MLGG, Eiras JC, Machado MH, SOUZA GTR AND PAVANELli GC. 2003a. The life cycle of Clinostomum complanatum Rudolphi, 1814 (Digenea, Clinostomidae) on the floodplain of the high Paraná River, Brazil. Parasitol Res 89: 506-508.

Dias MLGG, Minte-Vera CV, Eiras JC, Machado MH, SouzA GTR AND PAVANELli GC. 2006. Ecology of Clinostomum complanatum Rudolphi, 1814 (Digenea, Clinostomidae) on the floodplain of the high Paraná River, Brazil. Parasitol Res 99: 675-681.

Dias MLGG, Santos MJ, Souza GTR, Machado MH AND PAVANELLI GC. 2003b. Scanning electron microscopy of Ithyoclinostomum dimorphum (Trematoda: Clinostomidae) a parasite of Ardea cocoi (Aves: Ardeidea). Parasitol Res 90: $355-358$.

DIESING CM. 1850. Systema Helminthum. Volume 1. Vindobonae: Sumptibus Academiae Caesareae Scientiarum, Apud Wilhelmum Braun Müller, 679 p.

Dollfus RP. 1932. Mission Saharienne Augiéras-Draper, 1927-1928. Trematodes de mammifères, oiseaux et poissns. Bull Mus Natl Hist Nat 4: 555-563.

EirAS JC, TAKEMOTO RM AND PAVANELli GC. 2006. Métodos de estudos e técnicas laboratoriais em parasitologia de peixes. $2^{\mathrm{a}}$ ed., Maringá: Editora da Universidade Estadual de Maringá, 199 p. 
EIRAS JC, TAKEMOTO RM AND PAVANELli GC. 2010 Diversidade dos parasitos de peixes de água doce do Brasil. Maringá: Gráfica e Editora Clichetec, 333 p.

ForTES E, HOFFMANN RP AND SCARIOT J. 1996. Trematódeos digenéticos de Hoplias malabaricus (Bloch, 1794) do Lago Guaíba, Porto Alegre, RS, Brasil. Rev Bras Med Vet 18: 68-70.

Froese R AND PAULY D. 2012. Editors. Fishbase. World Wide Web eletronic publication. http://www.fishbase.org. Acessed: 07 April 2012.

Gallio M, Silva AS, Soares JF, Silva MK, Salomão EL AND MONTEIRO SG. 2007. Ocorrência de metacercárias de Ithyoclinostomum dimorphum em traíras no Rio Grande do Sul, Brasil: relato de caso. Estud Biol 29: 337-339.

Godoy MP. 1975. Peixes do Brasil. Bacia do Rio Mogi-Guaçu. Vol. 4. Piracicaba: Editora Franciscana, 398 p.

GraÇA WJ AND Pavanelli CS. 2007. Peixes da planície de inundação do alto Rio Paraná e áreas adjacentes. Maringá: Editora da Universidade Estadual de Maringá, 241 p.

KABUNDA MY AND SOMMERVILle C. 1984. Parasitic worms causing the rejection of tilapia (Oreochromis species) in Zaire. Br Vet J 140(3): 263-268.

KANEV I, RADEV V AND FRIED B. 2002. Family Clinostomidae Lühe, 1901. In: GiBson DI, Jones A AND Bray RA (Eds), Keys to the Trematoda. Volume1. London: CABI Publishing and the Natural History Museum, p. 113-120.

LENT H AND FReITAS JFT. 1937. Pesquisas helmintológicas realizadas no Estado do Pará. I. Trematoda. Mem Inst Oswaldo Cruz 32: 449-460.

LUNASCHI LI AND DRAGO FB. 2009. Digéneos parásitos de seis especies de aves de la provincia de Formosa, Argentina. Rev Mexic Biodivers 80: 39-46.

Machado MH, PaVANElli GC and TAKemoto RM. 1996. Structure and diversity of endoparasitic infracommunities and the trophic level of Pseudoplatystoma corruscans and Schizodon borelli (Osteichthyes) of the High Paraná River. Mem Inst Oswaldo Cruz 91: 441-448.

MANTER HW. 1970. The terminology and occurrence of certain structures of digenetic trematodes, with special reference to the Hemiuroidea. Fac Public Harold W Manter Lab Parasitol. H. D. Srivastava Commem Vol: 27-33.

MARINHO JA. 2005. Dinâmica das relações socioeconômicas e ecológicas no extrativismo do açaí: o caso do médio rio Pracuuba, São Sebastião da Boa Vista, Marajó (PA). Dissertation, Universidade Federal do Pará. (Unpublished).

MoreIRA NIB. 2000. Helmintos parasitos de peixes de lagos do médio Rio Doce, Minas Gerais, Brasil. Dissertation, Universidade Federal de Minas Gerais. (Unpublished).

MURRIETA RSS, BAKRI MS, ADAMS C, OLIVEIRA PSS AND STRUMPF R. 2008. Food intake and ecology of riverine populations in two Amazonian ecosystems: a comparative analysis. Rev Nutr 21(Suppl.): 123-133.

OYAKAWA OT. 2003. Family Erythrinidae. In: ReIS R, Kullander S and Ferraris C (Eds), Check List of the Freshwater Fishes of South and Central America. Porto Alegre, EDIPUCRS, p. 238-240.
OYAKAWA OT AND MATTOX GMT. 2009. Revision of the Neotropical trahiras of the Hoplias lacerdae speciesgroup (Ostariophysi: Characiformes: Erythrinidae) with descriptions of two new species. Neotrop Ichthyol 7: 117-140.

PARAGUASSÚ AR AND LUQUE JL. 2007. Metazoários parasitos de seis espécies de peixes do reservatório de Lajes, Estado do Rio de Janeiro, Brasil. Rev Bras Parasitol Vet 16: 121-128.

PAVANELli GC, SCHAEFFER GV AND SANTOS MHM. 1990. Ocorrência e histopatologia de metacercárias de Ithyoclinostomum dimorphum (Diesing, 1850) (Trematoda - Clinostomidae) em traíras coletadas no rio Paraná. Rev Unimar 12: 69-75.

Pinto RM, BARros LA, TORTElly L, TEIXEIRA RF AND GOMES DC. 2004. Prevalence and pathology of helminths of ciconiiform birds from the Brazilian swamplands. J Helminthol 78: 259-264.

RODRIGUES AP. 2010. Helmintos parasitos de Hoplias malabaricus (Ostheichtyes: Erytrinidae) comercializados na região sul do Rio Grande do Sul. Dissertation, Universidade Federal de Pelotas. (Unpublished).

Tiewchaloern S, UdomkiJdecha S, Suvouttho S, CHUNCHAMSRI K AND WAIKAGUL J. 1999. Clinostomum trematode from human eye. Southeast Asian J Trop Med Public Health 30(2): 382-384.

TRAVASSOS L. 1922. Informações sobre a fauna helminthologica de Mato Grosso. Trematódeos. Folha Médica 3(24): 187-190.

Travassos L. 1928. Fauna helmintológica de Mato Grosso (trematódeos 1 ${ }^{\mathrm{a}}$ parte). Mem Inst Oswaldo Cruz 21: 309-341.

TRAVASSOS L. 1940. Relatório da terceira excursão à zona da Estrada de Ferro Noroeste do Brasil realizada em Fevereiro a Março de 1940. Mem Inst Oswaldo Cruz 35: 607-696.

Travassos L AND Freitas JFT. 1941. Relatório da quinta excursão do Instituto Oswaldo Cruz, realizada à zona da Estrada de Ferro Noroeste do Brasil, em Janeiro de 1941. Mem Inst Oswaldo Cruz 36: 263-302.

Travassos L AND FreITAS JFT. 1942. Relatório da sexta excursão do Instituto Oswaldo Cruz, realizada à zona da Estrada de Ferro Noroeste do Brasil, em Novembro de 1941. Mem Inst Oswaldo Cruz 37: 259-286.

Travassos L, Freitas JFT AND KoHn A. 1969. Trematódeos do Brasil. Mem Inst Oswaldo Cruz 67: 1-886.

Travassos L, Freitas JFT AND MENDONÇA JM. 1964 Relatório da excursão do Instituto Oswaldo Cruz ao norte do Estado do Espírito Santo, junto ao Parque de Reserva e Refúgio Soóretama, em outubro de 1963. Bol Mus Biol Prof Mello-Leitão 23: 1-26.

VIANA L. 1924. Tentativa de catalogação das espécies brasileiras de trematódeos. Mem Inst Oswaldo Cruz 17: 95-227.

WEIBLEN AM AND BRANDÃO DA. 1992. Levantamento parasitológico em Hoplias malabaricus Bloch (1794) (traíra) de águas da região de Santa Maria-RS. Cienc Rural 22: 203-208.

WILliams H AND JONES A. 1994. Parasitic worms of fish. London: Taylor \& Francis Ltd., 593 p. 